\title{
EDITORIAL NOTE \\ The role of RNA in genetic programming, the interaction between humming birds and angiosperms in two areas of the Serra da Bodoquena (Mato Grosso do Sul, Brazil), and new extinct flying reptiles from China
}

\author{
ALEXANDER W.A. KELLNER \\ Editor-in-chief
}

This issue of the Anais da Academia Brasileira de Ciencias (AABC) is very special since, for the first time, this journal has published over 1000 pages in a year. There are 29 articles that cover different scientific disciplines, from mathematical sciences to vertebrate paleontology, providing important advances in these fields.

Among the highlights of the present issue is the contribution of John S. Mattick (University of Queensland, Brisbane, Australia) regarding genetic programming. For the last 50 years or so, there has been a general believe that most of the genetic information for multicellular organisms is transacted by proteins. The starting point for this assumption is the general 'DNA makes RNA makes protein' dogma (e.g., Mattick 2010). Although this might work for simple unicellular prokaryotes, there is growing evidence that RNA plays a more central role in the genetic programming system for eukaryotes. The present approach is that the genomes of complex organisms, here including humans, can be regarded as islands of protein-coding sequences (e.g., Ovcharenko et al. 2005), with RNA carrying out the major role regarding regulation. As observed previously, this molecule can form rather sophisticated structures among others) whose study - as Mattick (2010) points out - might hold the key to understand human evolution with far more outreaching possibilities than previously thought, including the comprehension of individual susceptibilities to complex diseases.

As has been pointed out several times in the literature, phenology and pollination are paramount in the reproduction of plants. While phenology is concerned with a variety of factors such as interactions between plants and animals, including annual cycles and seasonal rhythms of individual plant species (e.g., Talora and Morellato 2000), research on pollination focus on factors such as the amount of mutual dependence among species that encompasses the resource and supply for pollen vectors (e.g., Smith-Ramírez et al. 2005). In an interesting study published in this issue of the AABC, Rogério R. Faria and Andréa C. Araújo from the Universidade Federal do Mato Grosso do Sul (Campo Grande) discuss the interaction between hummingbirds (which are considered among the most effective pollinators, particularly in the neotropics) and bird-pollinated plants in two areas of the Serra da Bodoquena situated in the mid-south region of Mato Grosso do Sul. This type of study might help us to better understand the effects of deforestation in the local biota, particularly in Mato Grosso do Sul State, where agriculture is expanding rapidly in the last decades at the expense of the indigenous forests.

Lastly, the present issue of the AABC presents the description of two almost complete extinct flying reptiles from China. For more than a decade, Chinese fossils have been standing in the spotlight of Paleontology particularly due to the exceptionally well-preserved material coming from what is known as the Jehol Biota, which is found mostly 
EDITORIAL NOTE

in the Yixian and Jiufotang Formations (e.g., Zhou et al. 2003). Most recently, however, several new specimens have also been unearthed in stratigraphic units that are older and that are referred in the literature as the Daohugou or Tiaojishan Formations (Wang et al. 2010), particularly from a region called Linglongta (western Liaoning). Among these are remains of what is perhaps the most interesting clade of pterosaurs (an extinct group of flying reptiles) discovered in the last years: the Wukongopteridae. This group of pterosaurs, which was proposed in a paper published by the AABC (Wang et al. 2009) revealed a quite unusual combination of primitive and derived characters of a new species, Wukongopterus lii, which became even more apparent with the discovery of Darwinopterus modularis from the same deposits (Lü et al. 2010). Here, Xiaolin Wang (Institute of Vertebrate Paleontology and Paleoanthropology, Chinese Academy of Sciences, Beijing, China) and colleagues report two new species that can be attributed to the Wukongopteridae (Wang et al. 2010). In several color plates, these authors unravel the detailed anatomy of these flying reptiles that proved to be more diversified than previously known and surely will open a new chapter in pterosaur studies.

\section{REFERENCES}

FARIA RR AND ARAÚJO AC. 2010. Flowering phenology and pollination of ornithophilous species in two habitats of Serra da Bodoquena, Mato Grosso do Sul, Brazil. An Acad Bras Cienc 82: 843-855.

LÜ JC, UNWIN D, JIN X, LIU Y AND JI Q. 2010. Evidence for modular evolution in a long-tailed pterosaur with a pterodactyloid skull. Proc R Soc B 277: 383-389.

MAtTICK JS. 2010. The central role of RNA in the genetic programming of complex organisms. An Acad Bras Cienc 82: 933-939.

Ovcharenko I, Loots GG, Nobrega MA, Hardison RC, Miller W and Stubbs L. 2005. Evolution and functional classification of vertebrate gene deserts. Genome Res 15: 137-145.

Smith-Ramírez C, Marinez P, Nuñez M, GonzÁlez C and Armesto JJ. 2005. Diversity, flower visitation frequency and generalism of pollinators in temperate rain forests of Chiloé Island, Chile. Bot J Linnean Soc 147: 399-416.

TAlora DC And Morellato LPC. 2000. Fenologia de espécies arbóreas em floresta de planície litorânea do sudeste do Brasil. Rev Bras Bot 23: 13-26.

Wang X, Kellner AWA, Jiang S, Cheng X, Meng X and Rodrigues T. 2010. New long-tailed pterosaurs (Wukongopteridae) from western Liaoning, China. An Acad Bras Cienc 82: 1045-1062.

Wang X, Kellner AWA, Jiang S And Meng X. 2009. An unusual long-tailed pterosaur with elongated neck from western Liaoning of China. An Acad Bras Cienc 81: 793-812.

Zhou ZH, BarRett PM And Hilton J. 2003. An exceptionally preserved Lower Cretaceous ecosystem. Nature 421: $807-814$. 